\title{
Festival of school teachers as a practice-oriented form of improving teachers' skills ${ }^{1}$
}

\author{
Elena E. Merzon a \\ Yury V. Senko ${ }^{b}$ \\ Elena V. Salimullina ${ }^{c}$
}

\section{Abstract}

The article discusses the formation of the authorial position of the teacher at the Festival of school teachers as innovative forms of improvement of their professional competence. The author's position is transforming the understanding of the meeting the teacher is the moderator of the Festival and is a potential point of entering them both in professional culture. Hence discussed in the humanitarian paradigm the focus of the author's position direct participants in educational meetings, manifested in accessing professional - wider - life experiences with each other and with the idea, the sentiment, the co-action. Disclosed humanitarian treatment "teacher-moderator", which constitutes the process of training and gives them the meeting pedagogical sense.

Keywords: Professional competence. The author's view of the teacher. Educational technology. The style of the new pedagogical thinking.

\section{Introduction}

The increasing role of education in today's information society defines the priority objective for the development of modern education in Russia, Brazil, and other countries. This concerns the need for raising the professional level of teachers, namely strengthening teachers' authorial position as the basis of professional competence. In addition to being creative and socially active, today's role-model teacher states he or she should be the one who is able to prepare a student for life in this rapidly changing world. Since the society's literacy level

\footnotetext{
This article has been written with funding from Russian Humanitarian Science Foundation (Grant No. 13-0600010, project type "a").

a Department of Nursery and Primary Education Theory and Methodology. Elabuga Institute (Branch) of Kazan Federal University. Republic of Tatarstan, Volga Federal District, Russian Federation.

b Department of Pedagogics of Higher School and Information Educational Technologies. Altai State University. Altayskiy Kray, Russian Federation.

Kazan Federal University. Republic of Tatarstan, Volga Federal District, Russian Federation.
} 
has been increasing in recent years, and more and more people choose to send their children to study in public schools, the school must meet the society's needs and offer a more dynamic system for learning the educational material instead of simply reading a textbook. In this connection, there is a need for searching new content, technologies and forms of teachers' professional growth. The authors of this article suggest getting acquainted with the practice of the Festival of School Teachers as a form of pedagogical education.

As a platform for the organization of professional interaction among teachers, the Festival allows integrating various forms of teachers' intellectual and sociocultural activities and providing an opportunity for a free exchange of views on the development of education, self-presentation, as well as a discussion of a set of problems in their totality and interrelationship. In addiction, the festival form implies an intensive program of events that unite the participants of the festival in the unique atmosphere of education as a form of life and activity (Merson; Savina, 2012, p. 337).

The main activities of the Festival include:

- teachers' presentation of innovative educational projects in both theoretical and practical components;

- free exchange of experience in solving educational tasks;

- participation in discussion platforms and round tables where teachers, administrators of education, as well as workers of trade unions, foundations, and cultural organizations, etc., gather together and discuss ways of further development of education, which allows outlining integrated solutions to the emerging problems.

The Elabuga Institute of Kazan Federal University is located in the territory of Elabuga, a city-museum of federal significance, and has more than a century's history of teacher training. Therefore there is no coincidence that it became the venue of the Festival.

The Festival of School Teachers presupposes a few days of intensive professional communication (Merzon; Rzzhivin, 2013, p. 252). The festival does not focus on lecturing or conducting seminars and practical classes by teachers from domestic and foreign higher education institution. The most significant peculiarity of the Festival consists in moderation as a way of involving festival participants in 
collegial activities based on the experience of a moderator whose effectiveness has been verified. Higher education institution employees and practicing teachers who act as moderators present their own experience and motivate the audience to produce their own ideas and exchange achievements, which well contributes to all participants' professional growth. Thanks to this, the Festival has a high potential because it unites all participants in a common atmosphere of mutual demand and trust and is supported by the uniqueness of participants. In 2012, the second year of its operation, the Festival went beyond the regional level and became International.

\section{Method}

The problems of renewing and improving teachers' professional competence are widely discussed around the world. This is related to the fact that the leading role in ensuring quality education is axiological in modern times. For example, the works of Canadian and American researchers (Beck; Kosnik, 2002; DarlingHammond; Bransford, 2005; Kosnik et al., 2002; Fullan, 2007a; Hargreaves, 2009; Meeuwse; Mason, 2017) cover in detail the problems of continuing education. The monograph of J. McNally and A. Blake (2010) was devoted to the problems of improving education in the context of teachers' professionalism in the cognitive and effective components of their activities. J.K. Rice's (2013) monograph touches upon the possibility of actively using one's own experience in the system of teachers' support and professional growth. The authors of this research took special interest in L. Darling-Hammond and N. Richardson's (2009) monograph about the ways of increasing the effectiveness of teachers' work through their own training. Thus, it is possible to state that there has been an active search for forms of teachers' continuing education. The authors of this research suggest getting acquainted with the practice of the Festival of School Teachers as an educational platform for teachers' personal and professional self-determination, as well as comprehension and development of their authorial position.

This article is based on authors' personal experiences in organizing the Festival, conducting master classes, and co-participating in the formation of teachers' authorial positions.

The methods used in the research include:

- the method of observation, which allows recording the phenomena under investigation (the activeness of the Festival participants during master classes, trainings, business games, etc.; their willingness to communicate with colleagues and demonstrate their own experience; readiness to accept the pedagogical world and the image of the Other; involvement in creative 
competitions that are organized within the framework of the Festival, and empathy for others' experiences);

- the analysis of advanced pedagogical experience, which allows describing and systemizing the results of a teacher's professional activity, revealing the essence of a teacher's experience and the conditions for its effective application;

- the method of conversational interviewing, which gives an opportunity to teachers to present their own experience, and receive approval and support from their colleagues in the field of pedagogy;

- the analysis of the activity products, which allows understanding teachers and the essence of their professional skills through the "disobjectification", analysis and interpretation of material and ideal (texts, pictures, music, comments, speeches, solutions to pedagogical situations) products of teachers' activity;

- modeling as a form of expressing the meanings of their work in school and demonstrating their own professional positions;

- the method of introspection, which allowed the teachers to comprehend their own experience and build the image of a successful teacher.

In order to determine the strategy for the further development of the Festival, the authors of the research conducted a survey of teachers, aimed at identifying the factors that determined their choice of a teacher's profession. The survey involved about 400 leading teachers, the participants of the Festival, from the Republic of Tatarstan and the Volga Federal District. Despite the fact that the Festival of School Teachers is international, the number of respondents from abroad is not statistically sufficient for making conclusions for other regions as well. According to the research hypothesis, the Festival will be in demand by the teachers' community in the event that it directly or indirectly influences a set of the most relevant factors.

The top 5 relevant factors include a decent salary (71\%), respect for a teacher's profession (58\%), teachers' feeling of their own importance and worthfulness of their work (44\%), and the opportunity of free creativity in their profession (42\%) followed by the love of students ( $15 \%$ for previous and $33 \%$ for current students).

Today the Festival actively influences such important factors for choosing a teacher's profession, as respect for a teacher's profession, teachers' feeling of their 
own importance, and the opportunity of free creativity in their profession. One is currently considering the idea to award active Festival participants (winners) with project scholarship by regional Ministry of Education and Science as a possible factor ensuring decent salaries. Another idea under consideration is to attract children to participate in the Festival's activities.

The results of the Festival of School Teachers have been published in a number of Russian and European scientific works.

\section{Results}

The peculiarity of the Festival consists in the polysemy of a teacher's positions (the positions of a listener, analyst, expert, moderator, etc.) during master classes, which enabled the teachers to realize the importance of understanding in the pedagogical process. The organization of the Festival participants' cooperative work, in which they go through internal problems, helps to understand a student's inner world and aim at it when building educational activities in the future. The main features of building relationships related to activity motives in professional interaction and the overcoming of dialogue barriers were highlighted during the project implementation. Teachers' acquaintance with theoretical provisions on the strategies of understanding was organized in the course of analyzing one's own activities and professional problems. The comprehension of one's own experience made it possible to identify the strategies of understanding one's own attitudes towards the content of education, the organization of problem situations, role plays in class, "penetrating" into the topic through associative perception, symbols, signs, work with the concepts of the hermeneutic circle, reconstruction of the era, comparison of the past and the future, inclusion in the historical context, reliance on human values, as well as the assembly of a working model through building an image.

Of course, the formation of a teacher's authorial position does not exhaust the educational effectiveness of such a multi-faceted and versatile form of improving professional competence as the Festival. For all the participants, each of the eight Festivals held within the framework of the compressed festival days became a "gymnastic hall" of humane relations, a school of creative initiative, a school where everybody teaches and learns, a school that familiarizes with professional culture as a living embodiment of the world of human values and meanings, and a school that is open to changes and works with reserves for advancing. 


\section{Discussion}

As already noted, improving a teacher's professional competence is one of the most important objectives of the Festival. The general cultural and professional competences are included in the professional culture of teachers, but are realized in their activity at the operational and, in the best-case scenario, the tactical level and under standard conditions. The strategy of a teacher's activity is determined by the universals of professional culture: the pedagogical worldview, the pedagogical image of the world of education, the professional image of a teacher's world, as well as his/her self-concept and authorial position. In their unity, the above-mentioned universals form a kind of matrix, a "system of coordinates", in which a teacher's professional life activity evolves. The authors of the research refer to the assessment of the role of universals in culture:

The system of universals is a kind of generalized program of social life. A huge array of specific programs of human life activities that constitute the "body" of the culture of knowledge, behavior and communication, beliefs and value orientations, and so on. Through these specific programs that are fixed and broadcast in the form of semiotic schemes, the universals determine this or that types of social relation, lifestyle, personality types, man's relation to nature, as well as the features of human communications (Stepin, 2004, p. 38).

The authorial position of a participant of the Festival acts as a basis for a teacher's professional competences. The authorial position consists in a transformative understanding of the "teacher-moderator" meeting and serves as a potential point for the "penetration" of both into culture. Hence, the direction of the authorial positions of the immediate participants in the educational meeting is viewed in the humanitarian paradigm and is manifested in turning to one another's professional experience - more broadly, life experience - for co-thought, cofeeling, and co-action. This is a holistic multi-level system of teachers' notions about the pedagogical process, about themselves and other participants in the process, about their own and the other participants' activities in the process, which contains a meaningful coordinate. It is this coordinate that humanizes the authorial position and determines the humanitarian orientation of the pedagogical process (Merzon; Razzhivin, 2013).

In "statics", the authorial position acts as an integrative characteristic of a teacher's pedagogical culture, which includes the totality of relations to the teacher as a subject of professional activity and to the student as a subject of his/her own vital activity. This implies the need of the teacher "for respect of others, for gaining 
a status, attention, and recognition, as well as for self-actualization" (Maslow, 1999). In "dynamics", the authorial position manifests itself in the decentralization and reversibility of the Teacher towards the Student, and is characterized by awareness, humaneness, integrity, creativity, and originality. The formation of the authorial position presupposes the following conditions:

- the teacher's understanding of the pedagogical process as a humanitarian practice;

- the teacher's reflective attitude towards his/her own professional position;

- the organization of the pedagogical process based on the principles of new pedagogical thinking, namely the dominance of the Other, understanding, reflexivity, and metaphorically (Senko, 2011).

A teacher's authorial position changes extremely slowly and with great difficulty. As a dynamic stereotype of personality, it is much more "stereotyped" than "dynamic". Therefore, the teacher's overcoming of barriers in relations with students, as well as the formation of his/her own (authorial) position in his/her professional sphere require a lot of work and efforts. The effective overcoming of the above-mentioned stereotypes and barriers in a teacher's professional activity can be achieved on the way of the formation of a teacher's own authorial position as the universal of his/her professional culture.

First of all, both a teacher and a student will have to change their old approaches to thinking and acting. In this regard, they will have to reject a number of habitual positions in education and to shift the emphasis from the obvious to the less obvious. "Escaping" from obviousness is a way of overcoming the lack of humanitarian thinking in education. This "escape" presupposes a different style of pedagogical thinking, i.e. a different authorial position of a teacher, namely a humanitarian-oriented one. A teacher's authorial position in the humanitarian paradigm is demonstrated in Table.

1. Overcoming the understanding of the content of education as a part of exclusively scientific knowledge (apparently, this overcoming is related to the rejection of the archaic division of knowledge into academic and scientific knowledge, as well as the absolutization of the principle of scientifically in school education). The content of secondary education should be isomorphic with culture as "man's effort to be" (Mamardashvili, 1990) and as a condition for man's formation in culture and evolution in its context. 
Table. A teacher's authorial position in the humanitarian paradigm.

\begin{tabular}{|c|c|}
\hline The goal of education & $\begin{array}{l}\text { - creating conditions for revealing a student's } \\
\text { essential forces and forming his/her personality }\end{array}$ \\
\hline A teacher's attitude towards a student & - as relating to a subject of cooperative activity \\
\hline $\begin{array}{l}\text { A teacher's attitude towards himself/ } \\
\text { herself }\end{array}$ & $\begin{array}{l}\text { - as relating to an intermediary between the } \\
\text { spiritual world of a student and the world of } \\
\text { culture (man-man-world) }\end{array}$ \\
\hline The direction of cognition & $\begin{array}{l}\text { - as performing the personality of the cognizing } \\
\text { person (thinking in the world, two or more types } \\
\text { of consciousness; the student manifests himself/ } \\
\text { herself verbally or in other signs of culture) }\end{array}$ \\
\hline The style of thinking & $\begin{array}{l}\text { - humanitarian (principles of understanding, } \\
\text { dialogicality, the other's dominance, } \\
\text { reflexivity, and metaphoricity) }\end{array}$ \\
\hline $\begin{array}{l}\text { The basic form of organizing the } \\
\text { educational process }\end{array}$ & $\begin{array}{l}\text { - dialoguing as a way of appealing to others } \\
\text { for sympathy, co-thinking and co-action }\end{array}$ \\
\hline Values & $\begin{array}{l}\text { human beings, values of creation, emotions, } \\
\text { duty, responsibility, as well as revealing } \\
\text { grounds for a relationship of openness in } \\
\text { themselves and others }\end{array}$ \\
\hline The subject of pedagogical activity & $\begin{array}{l}\text { - building teacher-student interaction as a way } \\
\text { of "penetrating" into culture }\end{array}$ \\
\hline ctivity & - creative self-realization of teachers and students \\
\hline
\end{tabular}

Source: Kosheleva, 2010.

2. It is necessary to reject pedagogical "arrogance" manifested in assessing the evolution of a student's personal experience as narrow, limited, and irrelevant in comparison with scientific knowledge. Although limited as compared with scientific knowledge in narrow "gnosiological" terms, a student's life experience has potentially broad opportunities in terms of education, aimed at getting acquainted with "someone else's" experience to make it into "his/ her own". After all, assimilation implies the amalgamation of someone else's and one's own experiences.

3. The recognition of self-worthfulness and importance for the formation of a student's own experience implies the recognition of the bearer of this experience as an equal participant in the educational process. This is possible provided that the teacher refuses to assess his/her own role in education as leading and "forward-looking" everywhere and all the time and shifts to the position of "the other's dominance" (Ukhtomsky, 2008). In other words, paternalism should be rejected as a universal principle of the constructing the pedagogical process in school. 
As a result of the above-described rejection, the arrangement of the heroes of the drama performed on the stage of education will undergo a change and will shift from the usual and obvious (the teacher and the content of education oriented towards the student). Thus, there will be a fundamentally different image, namely the teacher together with the students oriented towards new knowledge. "Together with the students" implies the refusal (or, at least, the restriction) of the usual and obvious model of school education as "filling" (children are viewed as "bags" for the program) of students who are taught scientific and other knowledge once obtained by somebody else. A completely different model, implemented at the Festival, which consisted in the joint construction of living knowledge, presupposes productive interaction of the teacher and students with the fragment of culture once obtained by somebody else. This concerns the strategic arrangement of participants in the pedagogical process. One side of the educational "barricade" is intended for the teacher and the moderator of the Festival, while the other side is intended for the fragment of the culture formed. As for the mise-en-scène in education, this arrangement can vary from traditional to innovative. In other words, it is necessary to shift the emphasis from the enlightening ("filling") model of education to the cultural model.

4. The transformation of culture into living knowledge and the construction of personal knowledge implies a shift from monologue to dialogue. Either by an exchange of significations or by personal meanings, the dialogue creates conditions for the immediate participants' complicity in the educational process. The participants of the actual pedagogical process are neither the teacher and the student, nor the teacher and the moderator of the Festival (these being their social roles, functions and masks), but living people brought together around meanings of education - the authors and heroes of the "drama" performed on the stage of education. In this regard, an academic discipline is not a goal, but a reason and a condition, i.e. a ground for the "teacher-moderator" interaction. This means that a lesson, a class hour, or a master class are not simply pedagogical events, but an event and a joint experience (not serving!) of two (and many) individuals in the horizon of a personality. Of course, there are still specific situations in the educational practice, in which there arises a need for productive a monologue. However, as a style of interaction between a teacher and a student, as well as the student and the content of education, monologue significantly limits the possibilities of education, since it is inadequate to the humanitarian nature of the educational process.

5. The intellectual and rational nature of education and professional activity does not stimulate a teacher's reflection on this particular nature of education. Moreover, the gnostic component in the structure of a teacher's professional 
activity is viewed as a kind of a "pivot" that centers its constructional, organizational, and communicative components. At the same time, the vertex component of a teacher's methodological culture, i.e. the style of a teacher's professional thinking, may lose humanitarian orientations. Reducing the educational process to a rational process draws education into a "sciencelearning" circle, a "discipline-centered" circle.

The authors of this article made an attempt to present a teacher's methodological transition from the paternalistic authorial position to the position of the other's dominance as a way of overcoming the obvious in negative terms. In a "positive context", this transition implies the construction of the educational process based on the principles of new pedagogical thinking, namely the principles of the other's dominance, understanding, dialogicity, reflexivity, and metaphoricity. Each of these principles evolves separately and independently of the others. They do intersect at some point, namely the humanitarian authorial position of a teacher. This point is not a final destination or a pole, where meridians meet, but rather a reference point - the direction of the formation of a teacher's authorial position in both professional and other (general, complementary) forms of education. The Festival of School Teachers creates the environment that helps teachers to obtain new pedagogical thinking and consolidate the authorial position (Figure 1).

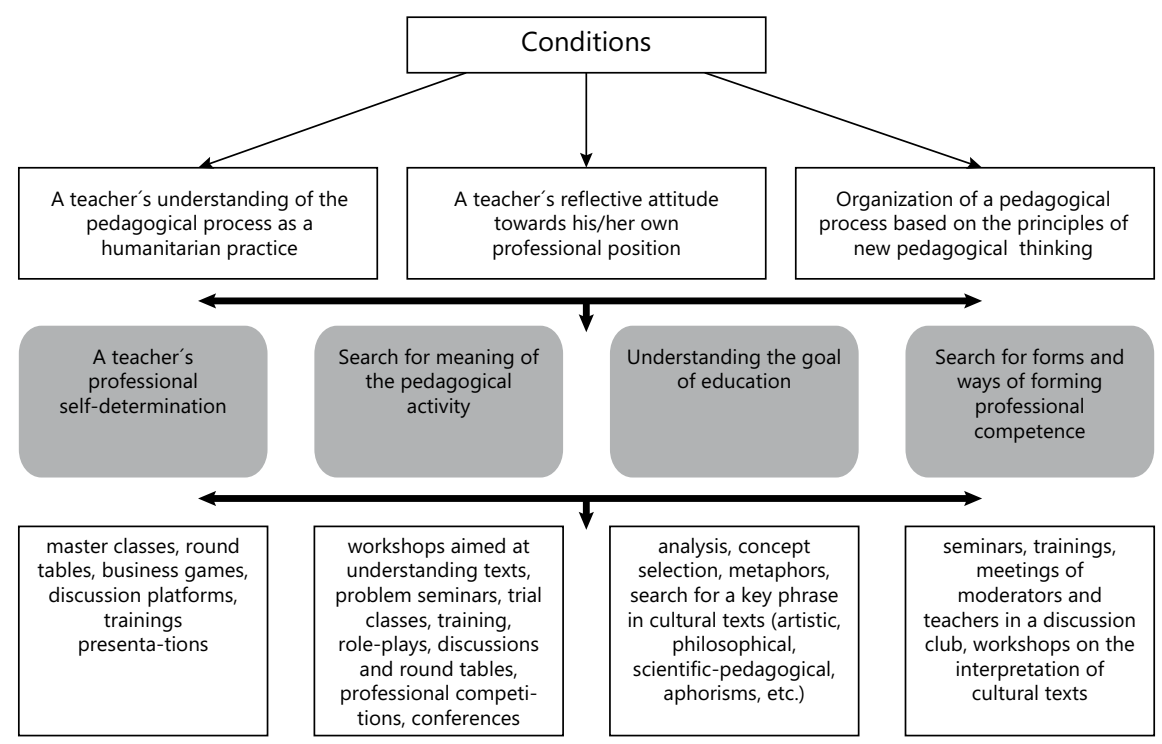

Source: Elaborated by the authors, 2017.

Figure 1. Formation of the authorial position of a teacher taking part in the Festival. 
The understanding that a teacher needs to change himself/herself to improve professional competence conditions the idea of the Festival and the logic of its work. In this regard, Rogers (1994) notes: "Is there a better way of learning something, than by involving all of yourself, your individuality, your deepest motives, emotions, attitudes and assessments into the process?!". A teacher's diligence, as well as personal and professional self-determination are the most important conditions for the personal and (possibly) professional self-determination of his/her students. In this respect, the Festival of School Teachers is viewed as a platform for defining and redefining of the authorial position of a practicing teacher.

This approach is concretized by means of master classes, round tables, business games, discussion platforms, trainings, and presentations proposed by moderators "Designing Educational Space in School" (Vinogradov V.L., Russia); "Analysis of Pedagogical Situations in the System of Teacher-Student Interaction" (Kaflik I., Poland); "Problems of Pedagogical Understanding" (Frolovskaya M.N., Russia); "Supervision by the Method of Psychodrama" (Budai Y., Hungary); "Problems of Mathematical Education in Russia and the USA" (Choshanov M., USA); "Identification and Development of Gifted Students through a Comprehensive Educational and Diagnostic Technology" (Kozinets L.A., Belarus); "From the Experience of the Montessori School" (Gabriela Lenka von Dühring-Kripp, Switzerland); "Increasing Schoolchildren's Interest in Studying Natural Sciences" (Janzhai I., Thailand); "Didactics of Cooperative Learning" (Koinova-Zöllner J., Germany), "The Influence of Bilingualism on the Development of Creativity" (Leikin M., Israel), etc.). Despite their versatility and orientation towards the solution of their "own" specific tasks, all of them pursue a common goal, namely the goal of creating conditions for personal and professional self-determination of the teacher and the formation of his/her authorial position.

During the implementation of the project of the "Festival of School Teachers", it became clear that the content of the topics described consists in the process of changing its immediate participants, rather than the system of knowledge. Indeed, "[...] goal of education is not to be satisfied with the transfer of knowledge and traditions, but to improve the gift that gives a person the ability to find unique meanings" (Frankl, 1990, p. 295). In this connection, the organization of classes was based on the following factors: the problematization of the educational material and the teacher's comprehension of its value; appeal to the cognitive, motivational, and affective sub-structures of listeners; communication and joint search for solutions through a dialogue; adjustment, enriching and reconsidering of one's own experience; the teacher's comprehension of the polysemy of positions and viewpoints; the ability to adequately express one's thoughts in communication; attention to inner world of the teacher; pedagogical optimism, 
and the Festival participants' benevolent acceptance of one another in all the richness of their human manifestation. New forms of organizing work towards teachers' professional and personal development (workshops on understanding texts, problem seminars, pilot classes, trainings, role plays, discussions and round tables, professional competitions, conferences) allowed teachers' further optimized interaction with students during classes of "their own" discipline.

The classes with the participant teachers of the Festival and these teachers' further classes in the classroom with their colleagues were conducted in the following logic (Figure 2): revealing one's own values and meanings of pedagogical activity; creating situations of understanding in professional interaction; defining the barriers of understanding; familiarizing teachers with the fields and strategies for understanding, as well as reflecting one's own educational practice.

During the Festival, the participant teachers themselves became moderators and successfully conducted master classes on the vital problems of school "Organization of Individual Work on Mistakes in Russian Language Classes", "Using Non-Traditional Techniques in Artistic Creativity as a Means of Improving Teachers' Professional Competence", "Modern Educational Technologies during Classes of Foreign Language, Russian Language and Literature, Biology and Chemistry, Mathematics and Computer Science, Tatar Language and Literature in Primary School...".

One of the ways to develop professional competence was related to organizing situations of understanding in professional interaction. For this purpose, design and modeling training sessions on diverse disciplinary content, seminars (Directing a

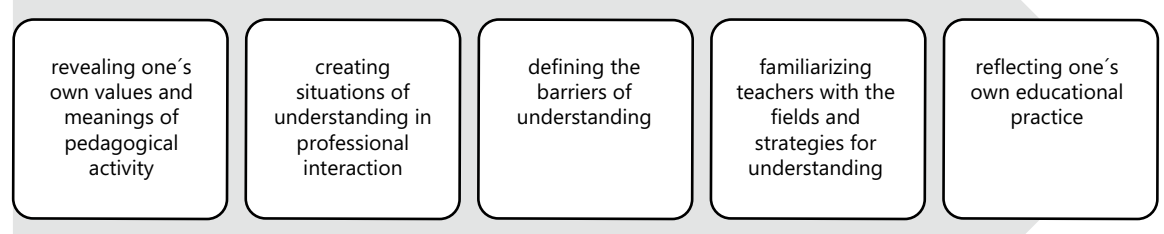

Source: Elaborated by the authors, 2016.

Figure 2. The logic of classes with teachers participating in the Festival. 
Lesson", "Creativity as a Pledge of a School Teacher's Success", "Technology of Learning and Cooperation", etc.), trainings, meetings of moderators and teachers in a discussion club, as well as workshops on the interpretation of cultural texts were organized within the framework of the Festival.

A teacher is traditionally a mediator between the world of culture and the world of a student. Interestingly, in the course of practical development of teachers' own classes, the role of the mediator between the "formed" culture and the culture of the teacher was assigned to the students. They contributed to the teacher's reconsideration of his/her own position and shift from disciplinary reflection to methodology and personal relations. This was the case when it was possible to speak about the teacher's willingness to learn from his/her students.

The reflection of practical work allowed the teachers to draw conclusions about valuable and meaningful professional orientations that include: the birth of personal meaning that appears upon the birth of a "new" text; formation of living knowledge as a way to understanding oneself; interaction with the Other in a dialogue that allows better understanding of oneself and the Other, as well as understanding the importance of one's own open position in the dialogue.

The authors of this article find it important to consider the "teacher-moderator" interaction in detail. The main characteristic of the cultural act is the moderator's transformative understanding of his/her interaction with teachers, which takes place in three interrelated fields simultaneously: disciplinary (as an understanding of the ways of dealing with a subject of culture), discursive (as an understanding orientation in the semiotic space of culture), and humanitarian (as a focus on personal meanings of the co-participants in the cultural act).

Even with explicit discipline-centered settings created by the moderator, when his/her understanding undergoes a displacement (deformation) in the first and second fields, the given didactic context - whether intentionally or unwittingly forces the moderator to "pay attention" to all the listeners (the plural number is an essential factor) in the averaged act of a disciplinary action. This is the case when the image of each individual teacher obviously remains ossified and reduced to an objective (proprietary) function. In the best-case scenario, the objective action is supplemented by a semiotic transformation, namely mastery of the discipline language (unfortunately, the language of a discipline often turns out to be devoid of traces of its disciplinary grounds, and the discipline itself turns out to be devoid of traces of the human practice that discovered the given discipline). 
The moderator who works in the humanitarian field of understanding is in an equally complicated (however, this complication is of a fundamentally different nature) situation. In the humanitarian field of understanding, the teacher (the listener) is represented exclusively in otherness that is set substantively, mainly through a text that is used by the teacher to envelop himself/herself. The moderator can get through to the soul of the Other (and thus, to his/her own soul too) only if they are able to disobjectify their own means of communication and discover his/her affective-sensual features. In particular, the latter takes place when a discipline is viewed through the prism of the cultural and historical logic of its development and formation as a means of communication. The classic of pedagogy, Sukhomlinsky (1982), formulated this idea in a most precise way:

When the discovery made by a scientist comes to life in human relationships and in the living impulses of thoughts and emotions, it becomes a complex task for a teacher who can solve it in a number of ways. A teacher's creative work consists in his/her choice of method and embodiment of theoretical truths in living human thoughts and emotions (p. 10).

Needless to say that in this case, a discipline turns into a means of rational and value-oriented attitude of a moderator and a teacher to each other, and thus acquires a semantic coloring.

It is necessary to draw attention to the intentional use of the term "disobjectification" - to "disobjectivify", but not to reject a discipline. The reason is not solely the authority of a discipline. The moderator has to consider his/her "own" discipline as a potential means of a teacher's self-expression. In order to clarify this, the authors of this article refer to A.A. Ukhtomsky's (2008) reflections on the distinction between communication and appeal as a cultural form, which he described as

[...] concentrated intercommunication with meeting people when they are deeply read and are provided with responses to their doings that are not yet perceived by themselves and are only sweeping along in the subconsciousness - ready to open up (p. 110).

Frankl (1990) adhered to the same viewpoint and asserted the rootedness of human meaning in the consciousness of one's own anticipation. In this context, a disciplinary appeal is a discipline-gifting. Moreover, a gift shall come from the soul, since "the soul is the gift of my spirit to another." This means that the subject is the result of the moderator's mental work presented as living knowledge 
that always bears a stamp of doubt. However, doubt, in its turn, requires an interlocutor (and, therefore, a co-opinion). In the search for its resolution, the moderator turns to teachers. However, the question is much of a deeper nature and can be formulated in the following way: "What is necessary for a pedagogical appeal to take place?"

The answer turns out to be paradoxical: the hearing of the appeal takes place when there is a Student - one who seeks answers to his/her (as a teacher at the Festival) questions. In this case, the moderator should answer not to his/her own questions, but to the Other's questions that are not yet signified for himself/ herself. At the same time, the moderator's is not to helping with significations, but preserving as much of the naming (lingual sense determination) as possible, passing over in silence and preserving the "charm" of the "unnamed" world for the time being. However, at this point, the moderator needs to keep silence himself/herself, i.e. sacrifice and give up on himself/herself. Consequently, unlike any other act of communication, an appeal is ready to give up (to refuse oneself) the object of its appeal in favor of the Student. It is assumed that by departing from the externally divided speech (activity) plan, the moderator must move on to the plan of the internally divided speech (activity) of his/her Student and thus become the Student's inner voice (ideally, Alter Ego).

When speaking about the disciplinary orientation of a teacher's authorial position, it is necessary to ask the following question: "What does the moderator actually create as an author in his/her pedagogical activity? Note that the authors do not use the verb "to do" (although activity is a form of creativity in its highest manifestations), but "to create", i.e. the pedagogue creates something that appears in the world in his/her own performance for the first time and transforms the world (for understanding) with its appearance not only for the moderator himself/ herself, but at least for those who are next to him/her, namely his/her listeners and colleagues. It is this very approach that uncovers the "minuteness" that is called the pedagogical world. It was the transformation of this world that the immediate participants of the Festival were occupied with. 


\section{Festival de professores como uma forma orientada para a prática de aperfeiçoamento das habilidades dos professores}

\section{Resumo}

$O$ artigo discute a formação da posição dos direitos autorais do professor no Festival de professores de escola, como forma inovadora de aperfeiçoamento da competencia profissional deles. A posição autoral está transformando a compreensão do evento no qual o professor é o moderador do Festival e é uma referência potencial na introdução de ambos na cultura profissional. Portanto, conforme discutido no paradigma humanitário, o foco na posição autoral direciona os participantes nas reuniões educativas, manifestadas no acesso as experiências profissionais e, mais amplamente, nas experiências de vida entre si e com a ideia, o sentimento, a ação-conjunta. A divulgação da atuação humanizada do "professor-moderador", que constitui o processo de formação, dá a eles o sentido pedagógico do evento.

Palavras-chave: Competência profissional. Visão do autor acerca do professor. Tecnologia educacional. Estilo do novo pensamento pedagógico.

\section{Festival de profesores como una forma orientada a la práctica de mejorar las habilidades de los docentes}

\section{Resumen}

El artículo discute la formación de la posición de derechos de autor del profesor en el Festival de profesores de escuela como formas innovadoras de mejora de su competencia profesional. La posición del autor está transformando la comprensión de la reunión el docente es el moderador del Festival y es un punto potencial para ingresar a ambos en la cultura profesional. De ahí que se discuta en el paradigma humanitario el enfoque de la posición del autor con participantes directos en los encuentros educativos, manifestado en el acceso a experiencias profesionales - de vida más amplia entre sí y con la idea, el sentimiento, la co-acción. Se divulgó el tratamiento humanitario "maestro-moderador", que constituye el proceso pedagógico de la reunión.

Palabras clave: Competencia profesional. Visión del autor sobre el profesor. Tecnología educativa. Estilo del nuevo pensamiento pedagógico. 


\section{References}

BECK, C.; KOSNIK, C. Components of a good practicum placement: Student Teacher Perceptions. Teacher Education Quarterly, v. 29, n. 2, p. 81-98, 2002.

DARLING-HAMMOND, L.; BRANSFORD, J. (Ed.). Preparing teachers for a changing world: What teachers should learn and be able to do. San Francisco: Wiley Sons, 2005.

DARLING-HAMMOND L.; RICHARDSON, N. Teacher learning: What matters?. Educational Leadership, v. 66, n. 5, p. 46-53, 2009.

FRANKL, V. E. Man's search for meaning. Moscow: Progress Publishing, 1990.

FULLAN, M. Change the terms for teacher learning. National Staff

Development Council, v. 28, n. 3, p. 35-36, 2007a.

HARGREAVES, A. A decade of educational change. Journal of Educational Change, v. 10, n. 2/3, p. 89-101, 2009.

KOSHELEVA, L. A. The formation of a teacher's authorial position. 2010. 232 p. Dissertation (in Pedagogics) - Kuzbass State Pedagogical Academy, Barnaul, 2010.

KOSNIK, C. et al. Pre-service teacher education in Ontario: Trends and best practices in an era of curriculum reform. Toronto: University of Toronto, 2002.

MAMARDASHVILI, M. K. How I understand philosophy. Moscow: Progress, 1990.

MASLOW, A. H. Motivation and personality. 2nd ed. Saint Petersburg: Eurasia, 1999.

MCNALLY, J.; BLAKE, A. (Ed.). Improving learning in a professional context: A research perspective on the new teacher in school. Oxon: Routledge, 2010.

MEEUWSE, K., MASON, D. Personalized professional learning for educators: Emerging research and opportunities. Hershey, PA: IGI Global, 2017.

MERZON, E. E.; RAZZHIVIN, A. I. Festival of school teachers: Experience of international pedagogical communication. In: INTERNATIONAL SCIENTIFIC AND PRACTICAL CONFERENCE, 2., 2013, Prague. Proceedings... Prague: [International Scientific and Practical Conference], 2013. p. 252-257. 
RICE, J. K. Learning from experience? Evidence on the impact and distribution of teacher experience and the implications for teacher policy. Education Finance and Policy, New York, v. 8, n. 3, p. 332-348, 2013. doi: https://doi.org/10.1162/EDFP_a_00099

ROGERS, C. A look at psychotherapy. Becoming a Human Being. Moscow: Progress Publishing, 1994.

SENKO, Y. V. Education in the Humanities Perspective. Barnaul: Altay University, 2011.

STEPIN, V. S. Genesis of Social and Humanitarian Sciences (Philosophical and Methodological Aspects). Questions of Philosophy, Moscow, n. 3, p. 37-43, 2004.

SUKHOMLINSKY, V. A. Conversation with a young principal. Moscow: Prosveshcheniye, 1982.

UKHTOMSKY, A. A. The face of the other. Saint Petersburg: Ivan Limbakh Publishing House, 2008.

\section{Informações dos autores}

Elena E. Merzon: Ph.D. (Pedagogics), Associate Professor. Department of Nursery and Primary Education Theory and Methodology. Director of Elabuga Institute (Branch) of Kazan Federal University - Republic of Tatarstan, Volga Federal District, Russian Federation. Contato: e.merzon@yandex.ru

Yury V. Senko: Dr. habil, member of the Russian Academy of Education, Professor. Department of Pedagogics of Higher School and Information Educational Technologies. Altai State University, Russian Federation. Contato: senko.yur@yandex.ua

Elena V. Salimullina: Assistant at the Department of Pedagoics, manager of the School Teachers Festival. Elabuga Institute (Branch) of Kazan Federal University, Republic of Tatarstan, Volga Federal District, Russian Federation. Contato: salimullinaelena@yandex.ua 